\title{
METODE TRANSFORMASI "CAKAR AYAM" UNTUK MEREDUKSI SEARCH-SPACE PADA INTRUSION DETECTION SYSTEM BERBASIS K-NEAREST NEIGHBOR
}

\author{
Kharisma Muchammad, Thomas Brian \\ Fakultas Teknologi Informasi \\ Institut Teknologi Sepuluh Nopember \\ Kampus ITS Sukolilo, Surabaya 60111 \\ kharisma_muchammad@yahoo.co.id,thomasbrian2112@yahoo.com
}

\begin{abstract}
Abstrak
Penggunaan Intrusion Detection System (IDS) pada jaringan komputer merupakan hal yang diperlukan untuk menjaga keamanan jaringan. Beberapa IDS berbasis $K$-nearest neighbor (KNN) memiliki akurasi yang relatif baik namun jika data training terlalu besar, waktu yang diperlukan untuk mendeteksi serangan juga meningkat. Waktu untuk deteksi bisa ditekan dengan mereduksi search space pada data training. Namun problem reduksi search space dengan mempertahankan kualitas deteksi masih merupakan problem terbuka. Pada artikel ini diajukan suatu metode transformasi "cakar ayam" berbasis jumlah jarak data ke centroid dan jarak data ke dua sub-centroid untuk mereduksi search space pada IDS berbasis $K$-nearest neighbor. Localized $K$ nearest neighbor dilakukan pada data yang telah tertransformasi. Eksperimen menggunakan agglomerative hierarchial clustering dengan Unweighted Pair-Group Method of Centroid pada dataset NSLKDD 20\% menunjukkan penurunan search space maksimum sebesar 38\% dengan tingkat akurasi sebesar $77.5 \%$. Tingkat akurasi dan specificity maksimum yang dicapai pada eksperimen sebesar $88 \%$ dan $88.3 \%$ dengan tingkat reduksi sebesar $12 \%$ dan tingkat sensitifity maksimum yang dicapai sebesar $80.2 \%$ pada tingkat reduksi $11 \%$. Berdasarkan eksperimen, luas search space dapat dikurangi sambil menjaga akurasi deteksi. Rasio tradeoff antara akurasi dan search space mungkin dapat diperbaiki dengan mengganti algortima clustering dengan divisive hierarchial clustring.
\end{abstract}

Kata kunci :

clustering, deteksi intrusi, keamanan jaringan

\begin{abstract}
Intrusion detection System (IDS) for computer network has became an essential needs to ensure network security. Some K-nearest neighbor (KNN) based IDS have a relatively good accracy in detecting attack, but the need to use all training data costs time consumption. Detection time cost can be reduced by reducing search space needed for the algorithm. The problem of search space reduction while maintaining decent accuracy still an open problem. In this Paper we propose a new transformation method "chiken claw" method. which based on sum of two distances. The first distance is the distance of data and its cluster. The later is distance of data to 2 of its cluster's subcentroid..This method is proposed to reduce the search space on $K$-nearest neighbor based IDS because the search is based on resulted one dimentional transformed data. Experiment using Unweighted Pair-group Method of centroid on NSLKDD 20\% shows maximum search space reduction $38 \%$ with $75 \%$ accuracy. Maximum accuracy and sensitivity in the experiment is $88 \%$ and $88.3 \%$ respectively with space reduction 12\%. Maximum sensitivity from experiment is at $80.2 \%$ with $11 \%$ space reduction. Based on experiments, search space can be reduced while maintaining accuracy. Search space-accuracy trade off might be improved by using different clustering algorithm such as divisive hierarchial clustering
\end{abstract}

Keywords:

clustering, intrusion detection, network security 


\section{Pendahuluan}

Kebutuhan akan keamanan pada sistem komputer telah menjadi suatu kebutuhan yang esensial. Salah satu permasalahan keamanan yang sering terjadi adalah serangan pada jaringan komputer. Salah satu cara untuk mengatasi permasalahan tersebut adalah dengan menggunakan sistem deteksi intrusi (Intrusion detection System/IDS).

IDS dapat dibagi menjadi 2 kelompok. Kelompok pertama adalah IDS berbasis signature dan kelompok kedua berbasis anomali. Kelompok pertama menggunakan basis data serangan yang dikenali untuk membedakan antara aktifitas normal dan aktifitas serangan. Keunggulan pendekatan ini adalah sumber daya yang diperlukan untuk memeriksa aktifitas yang dipakai relatif kecil (Garcia-Teodoro dkk, 2009). Kelemahan pendekatan ini adalah tidak mampu mengenali serangan yang tidak terdapat dalam basis datanya. Pendekatan kedua menggunakan suatu model normal untuk mendeteksi serangan. Aktifitas yang memiliki deviasi terlalu jauh akan dideteksi sebagai aktifitas serangan. Salah satu kelebihan pendekatan ini adalah mampu mendeteksi serangan yang baru karena tidak bergantung pada basis data (Garcia-Teodoro dkk, 2009). Kelemahan pendekatan berbasis anomali adalah sumber daya yang diperlukan untuk membentuk model maupun deteksi relatif lebih tinggi dibandingkandengan pendekatan metode pertama dan tingkat false positive yang lebih tinggi dibandingkan dengan IDS berbasis signature (Garcia-Teodoro dkk, 2009).

IDS berbasis anomali sendiri dapat dibagi menjadi beberapa kelompok berdasarkan metode untuk membentuk model normal maupun klasifikasi aktifitas. Salah satu kelompok tersebut adalah IDS dengan pendekatan machine learning dengan $K$ nearest neighbor. Beberapa contoh IDS yang menggunakan $K$-nearest neighbor untuk proses klasifikasi antara lain CANN (Lin dkk, 2014) dan TANN (Tsai dan Lin, 2009). Masalah yang dialami oleh kedua IDS tersebut antara lain search space yang dipakai adalah seluruh data training. Jika ukuran data training terlalu besar, waktu yang diperlukan untuk mendeteksi serangan akan meningkat secara drastis. Penelitian ini mengajukan skema transformasi baru untuk mengakomodasi pencarian secara lokal dengan mereduksi search space. Secara intuitif penurunan search space dengan metode clustering, secara umum dapat mempercepat proses pencarian terdekat. Hal ini terjadi karena data yang dicari dalam KNN biasanya berada dalam satu cluster meski pada beberapa kasus tertentu tetangga terdekat bisa saja berada pada cluster yang berbeda. Hal ini dapat terjadi jika ukuran cluster terlalu kecil dan jarak antar cluster relatif kecil.

Penggunaan centroid dikarenakan centroid dapat dianggap sebagai "wakil" dari data dalam suatu cluster dan jarak data dari centroid dapat dipakai unutk membedakan data dalam suatu dataset. Subcentroid dipakai karena jika jarak dari centroid dapat dipakai untuk membedakan data dalam suatu dataset, maka jarak ke subcentroid dapat dipakai untuk membedakan data dalam suatu cluster.

\section{KAJIAN LiteratUR}

Penggunaan K-nearest neighbor untuk mendeteksi intrusi jaringan telah dilakukan oleh beberapa penelitian, beberapa diantaranya (Lin dkk, 2014), (Tsai dan Lin, 2009), (Liao dan Vemuri, 2002), dan (Ma dan Kaban , 2013). Beberapa penelitian fokus pada transformasi fitur (Lin dkk, 2014), (Tsai dan Lin, 2009) dan beberapa pada penggunaan jarak baru selain jarak euclidean (Ma dan Kaban , 2013).

Pada TANN (Tsai dan Lin, 2009), transformasi fitur dilakukan dengan mencari luas total segitiga yang terbentuk antara data dan 2 dari 5 centroid. 5 centroid tadi dicari dengan algoritma $K$-means. Sedangkan pada CANN (Tsai dkk, 2014), transformasi fitur dilakukan dengan menjumlahkan jarak dari 5 centroid ke data dan satu tetangga terdekat dari data tersebut yang masih satu cluster. Hasil transformasi TANN maupun CANN kemudian dimasukkan ke $K N N$ untuk mendeteksi apakah data termasuk aktifitas serangan atau aktifitas normal.

Permasalahan yang terjadi pada kesemua metode tersebut adalah search space yang dipakai untuk $K N N$ tumbuh seiring dengan ukuran data training yang digunakan. Beberapa peneliti seperti Garcia dkk (2008) mengatasi hal ini dengan menggunakan komputasi parallel dengan teknologi CUDA dari NVIDIA namun tidak semua komputer dilengkapi dengan kartu grafis yang dapat melakukan hal tersebut sehingga teknik reduksi search space masih bisa dikatakan relevan.

Pada makalah ini, diajukan suatu skema transformasi fitur yang mengakomodasi reduksi search space dengan menjaga akurasi deteksi. 


\section{Metode YANG DiAJUKAN}

Alur metode yang diajukan dapat dilihat pada Gambar 1. Data training di-cluster dengan suatu algoritma clustering hingga didapatkan $K$ cluster dan $K$ centroid. Langkah kedua yang dilakukan adalah mencari 2 sub centroid dari tiap-tiap cluster. Langkah ini tidak perlu dilakukan pada cluster yang hanya memiliki 1 anggota. Langkah ketiga yang dilakukan adalah mentransformasi data pada tiap cluster.

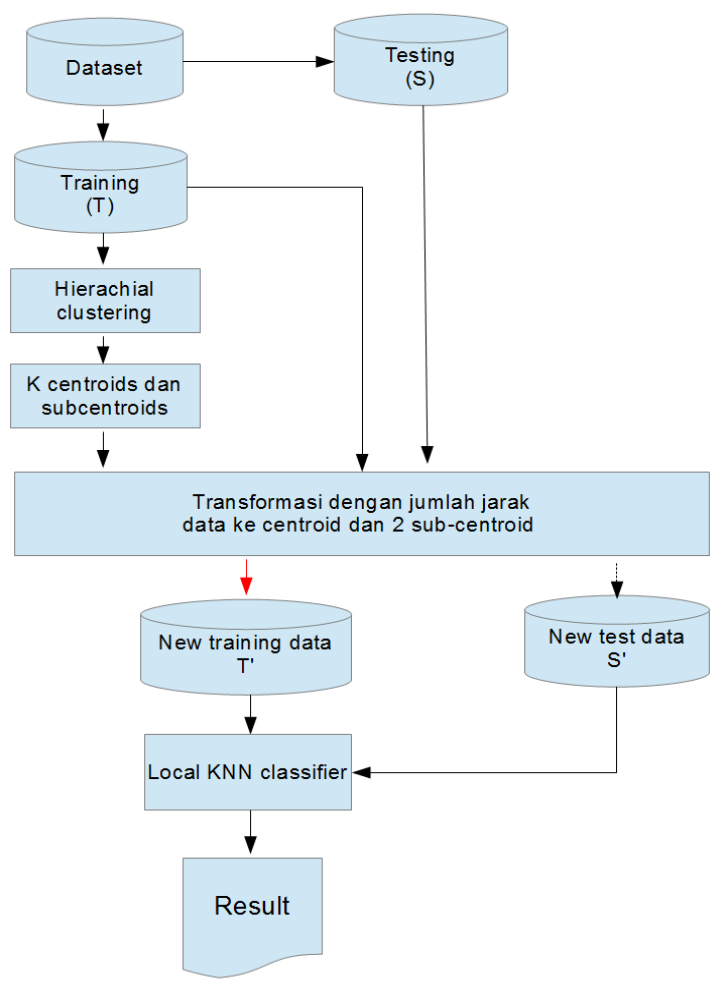

Gambar 1. Alur metode yang diajukan

Data ditransformasikan dengan persamaan (1) dimana $T$ adalah data yang akan ditransformasikan, $C$ adalah centroid yang paling dekat dengan $T, S C l$ adalah sub-centroid pertama dari $C$ dan $S C 2$ adalah sub-centroid kedua dari C. \|T-C $\|$ adalah jarak antara data cetroid. \|T-SC1\| dan \|T-SC2\| adalah jarak antara data dengan sub-centroid 1 dan sub-centoid 2 . Skema transformasi yang diajukan dapat dilihat pada Gambar 2. Seperti TANN dan CANN jarak ke centroid dipakai sebagai fitur untuk membentuk fitur baru namun karena tujuan dari metode ini adalah pencarian lokal, hanya jarak ke satu centroid yang dipakai. Dua sub-centroid dipakai karena jumlah subcentroid yang paling kecil dari cluster adalah 2, jika cluster tersebut tidak berisi satu data saja.

$T^{\prime}=\|T-C\|+\|T-S C 1\|+\|T-S C 2\|$

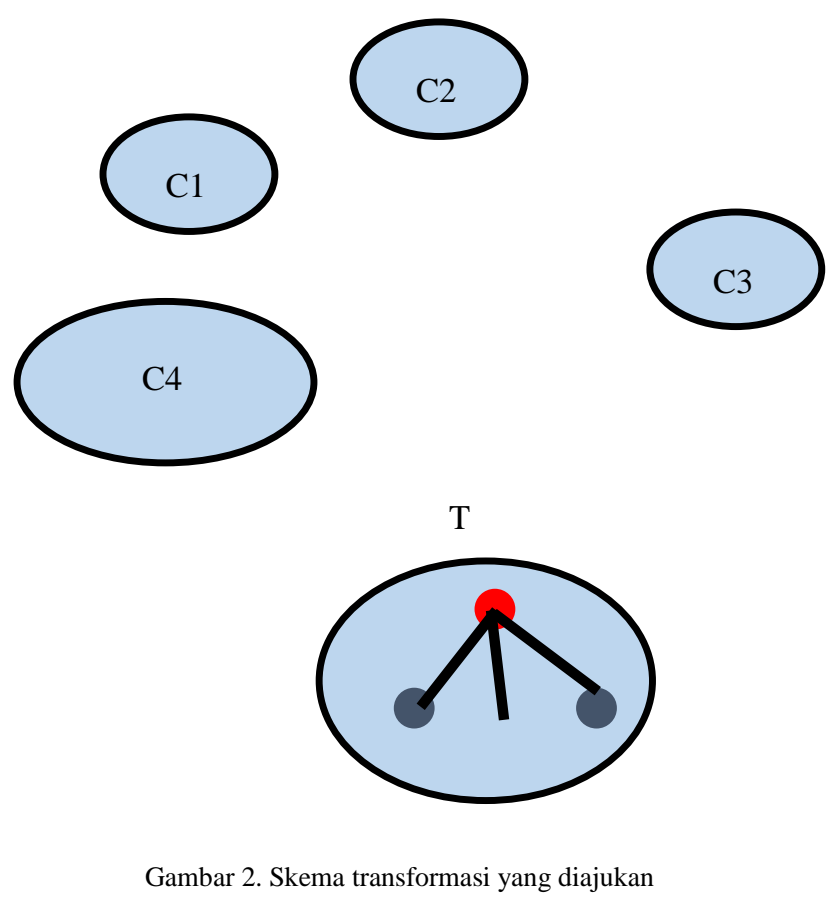

Pada fase testing, tiap data testing $S$ diletakkan pada cluster yang centroid-nya paling dekat, kemudian ditransformasi dengan persamaan [1] dan menghasilkan $S^{\prime}$. Data testing yang telah ditransformasikan tadi kemudian dicari $N$ tetangga terdekatnya yang masih 1 cluster dari data training yang telah tertransformasi.

\section{DESAIN EKSPERIMEN}

\section{IV.1 Dataset}

Dataset yang dipakai adalah dataset NSL-KDD $20 \%$ yang didapatkan dari (Cheng Hong). NSL-KDD merupakan hasil pengolahan dari KDD99 yang dipakai untuk kontes data mining KDD nuggets. KDD99 sendiri berasal dari dataset DARPA. Data NSL-KDD ini dihasilkan Tavallaee dkk (2009) karena dataset aslinya (KDD99) dianggap terlalu mudah untuk diolah sehingga mereka memilih 
sebagian data yang dianggap representatif dari dataset tersebut dan yang sulit untuk dideteksi.

Dataset ini berisi atribut koneksi dari klien ke server. Atribut yang dicatat terdiri dari 41 fitur antara lain tipe koneksi (TCP,UDP), lama koneksi (detik), jenis protokol (HTTP,FTP,SSH, dll) dan lain-lain.

Kolom yang dibuang adalah kolom protocol_type, service dan flag ketiga kolom ini dibuang karena data kategorikal tidak bisa diolah. Data duplikat kemudian dibuang dengan perintah Unix sort dan uniq. Data duplikat dibuang agar model yang dihasilkan tidak bias ke sekelompok data yang sering muncul. Statistik atribut pada dataset dapat dilihat pada tabel 1. Pada tabel tersebut dapat dilihat atribut apa saja yang dipakai dalam eksperimen ini, nilai rata-rata, nilai maksimum, nilai minimum, dan variannya. Untuk keperluan 10 fold cross validation data kemudian dipecah menjadi 10 partisi dengan komposisi tiap partisi dapat dilihat pada Tabel 2. Pada kolom pertama dapat dilihat label serangan dan kolom berikutnya distribusi jumlah data serangan yang terdapat pada partisi tersebut. Dapat dilihat pada Tabel 2 komposisi tiap partisi hampir sama.

\section{IV.2 Hierachial Clustering}

Algoritma hierarchial clustering yang digunakan dalam eksperimen adalah metode yang diusulkan oleh Bougettaya dkk (2014) dengan menggunakan UPGMC (Unweighted Pair-Group Method of Centroid) untuk mencari pasangan cluster yang paling dekat. Algoritma ini memerlukan 2 parameter dari pengguna. Parameter pertama adalah jumlah cluster awal $\left(\mathrm{K}_{\mathrm{awal}}\right)$ dan jumlah cluster final $\left(\mathrm{K}_{\mathrm{akhhi}}\right)$ dimana $K_{\text {awal }}>K_{\text {akhir. }}$ Eksperimen ini akan menggunakan beberapa nilai $\mathrm{K}_{\text {awal }}$ dan $\mathrm{K}_{\mathrm{akhir}}$ untuk melihat pengaruh kedua parameter tersebut terhadap akurasi deteksi.

\section{IV.3 K-Nearest Neighbor}

Nilai $K$ pada $K N N$ yang dipakai adalah 1 . Hal ini untuk memudahkan pembuatan confusion matrix, karena terdapat beberapa kelas dalam dataset.

\section{IV.4 Kriteria Penilaian}

Kriteria penilaian yang dipakai dalam eksperimen ini antara lain accuracy, sensitivity, specificity dan search space reduction. Rumus untuk mendapatkan ketiganya dapat dilihat pada persamaan [2], [3], [4] dan [5] dimana $T P$ adalah true positive, $T N$ adalah true negative, FP adalah false positive dan $F N$ adalah false negative. $\mathrm{S}_{\text {awal }}$ adalah jumlah data training awal dan $\mathrm{S}_{\max }$ adalah ukuran cluster paling besar pada seluruh skenario untuk parameter uji tersebut.

$\begin{array}{ll}\text { Accuracy }=T P+T N /(T P+T N+F P+F N) & \ldots[2] \\ \text { Sensitivity }=T P /(T P+F N) & \ldots[3] \\ \text { Specificity }=T N /(T N+F P) & \ldots[4] \\ \text { Reduction }=\left(S_{\text {awal }}-S_{\text {max }}\right) / S_{\text {awal }} & \ldots[5]\end{array}$

\section{IV.5 Hasil Eksperimen dan Diskusi}

Hasil eksperimen dapat dilihat pada tabel 3 dengan nilai paling tinggi untuk tiap kriteria ditebalkan. Dari tabel tersebut dapat dilihat pengaruh nilai parameter $K_{\text {awal }}$ dan $K_{a k h i r}$ pada akurasi ,sensitivity dan specificity. Makin besar $\mathrm{K}_{\text {awal }}$ dan makin kecil $\mathrm{K}_{\mathrm{akhir}}$ meningkat pula akurasi,sensitivity, danspesificity. Nilai akurasi terbesar didapatkan dari nilai $\mathrm{K}_{\text {awal }} 60$ dan nilai $\mathrm{K}_{\text {akhir }} 40$ sebesar 0.838 begitu pula nilai specificity sebesar 0.883 namun nilai sensitivity paling tinggi diraih pada nilai $\mathrm{K}_{\text {awal }} 60$ dan $\mathrm{K}_{\text {akhir }} 30$ sebesar 0.802 . Perbedaan minor akurasi pada $60 \quad 40$ dan $60 \quad 30$ mungkin terjadi karena fluktuasi pada algoritma clustering.

Nilai akurasi tersebut masih dibawah metode TANN (Tsai dan Lin, 2009) dan CANN (Lin dkk, 2014) sebesar 0.990 dan 0.997. Meski terjadi penurunan search space, penurunan akurasi pada metode ini terjadi lebih besar dari pada penurunan search space. Pada beberapa kasus mungkin hal ini tidak dapat ditolerir. Salah satu dugaan yang muncul untuk menjelaskan performa metode ini adalah data yang tidak dinormalisasi. Dugaan ini muncul melihat pada tabel 1 nilai varian, maksimum dan minimum tiap atribut tidak terdistribusi secara merata. Meskipun beberapa metode seperti CANN (Lin dkk, 2014) dan TANN (Tsai dan Lin, 2009) tidak memerlukan normalisasi data, mungkin metode ini memerlukan proses normalisasi untuk mencapai hasil yang lebih baik.

Kemungkinan lain yang mungkin menyebabkan performa yang sub-optimal adalah distribusi data pada dataset yang menumpuk pada satu cluster saja. Hal ini menyebabkan cluster tersebut berisi campuran data serangan dan normal. Hal ini sangat berpengaruh pada akurasi deteksi karena pada eksperimen ini pencarian hanya dilakukan secara lokal. Penggunaan algoritma clustering yang lain seperti divisive hierarchial clustering dengan 
minimisasi entropy mungkin dapat membantu meningkatkan akurasi deteksi. Dengan cluster yang homogen, secara intuitif, akurasi deteksi dapat ditingkatkan dengan mempertahankan tingkat reduksi karena kemungkinan besar ukuran cluster yang dihasilkan relatif kecil.

Nilai search space reduction paling tinggi didapatkan pada parameter $\mathrm{K}_{\text {awal }} 60$ dan $\mathrm{K}_{\text {akhir }} 60$ dengan nilai 0.386. Hasil ini sesuai ekspektasi dimana reduction rate akan meningkat seiring nilai $\mathrm{K}_{\mathrm{akhi}}$. Berdasarkan eksperimen, nilai space reduction masih jauh dari batas teoritis pada eksperimen dengan $\mathrm{K}_{\mathrm{akhir}} 60$ sebesar 0.983 dimana seluruh dataset dibagi secara merata menjadi 60 cluster. Tingkat reduction rate ini terjadi akibat penumpukan data pada satu cluster saja. Penggunaan divisive hierachial clustering mungkin dapat memperbaiki nilai ini.

Confusion matrix tiap eksperimen dapat dilihat pada tabel 4 hingga 7 . Pada kolom pertama adalah data aktual dan kolom berikutnya adalah hasil klasifikasi data tersebut. Pada seluruh eksperimen jenis serangan $u 2 r$ adalah yang paling sulit diklasifikasi. Hanya 1 data $u 2 r$ yang secara benar diklasifikasi yaitu pada eksperimen 6060 pada tabel 4. kebanyakan jenis serangan $u 2 r$ diklasifikasi sebagai aktifitas normal. Dalam hal ini performa CANN tidak jauh berbeda dengan performa metode ini dengan tingkat deteksi sebesar 3.85\%. Sedangkan dibandingkan TANN metode ini masih jauh dibawah dengan tingkat deteksi sebesar $60 \%$.

\section{KESIMPULAN}

Berdasarkan eksperimen diatas, metode yang diajukan menunjukkan nilai akurasi dan spesificity yang paling tinggi didapatkan pada nilai parameter $\mathrm{K}_{\text {awal }} 60$ dan $\mathrm{K}_{\mathrm{akhir}} 40$ sebesar 0.838 dan 0.883 dan tingkat reduksi sebesar 0.126 . Nilai sensitivity yang paling tinggi didapatkan dengan nilai parameter $\mathrm{K}_{\text {awal }}$ 60 dan $\mathrm{K}_{\mathrm{akhir}} 30$ sebesar 0.802 dan tingkat reduksi sebesar 0.113. Tingkat reduksi paling tinggi didapatkan dengan nilai parameter $\mathrm{K}_{\mathrm{awal}} 60$ dan $\mathrm{K}_{\mathrm{akhir}}$ 60 sebesar 0.386 .

Penelitian lanjutan dengan dataset yang berbeda diperlukan untuk validasi metode lebih lanjut. Berdasarkan hasil eksperimen penurunan search space dengan metode ini menimbulkan penurunan akurasi yang sama besarnya. Beberapa langkah yang mungkin dapat memperbaiki performa metode ini antara lain penggunaan divisive hierachial clustering.

\section{REFERENSI}

Bougettaya, A. Yu, Q., Liu,X., Zhou, X., Song, A.. (2014). Efficient Agglomerative Hierachial Clustering. Expert System with Applications, vol 42, pp. 2785-2798.

Cheng Hong Low: Tersedia : https://github.com/ defcom17/NSL_KDD

Garcia-Teodoro. P, Diaz-Verdejo. J, MarciaFernandez. G, Vazquez, E. (2009). Anomalybased network intrusion detection: Technique, system and challenges. Journal of Computers and Security, vol 28, no. 1, pp. 18-28.

Garcia. V, Debreuve. E, dan Barlaud. M. (2008). Fast K Nearest Neighbor Search using GPU. Computer Vision and Pattern Recognition Workshop. Pp. 1-6.

Lin, W.C., Ke, S.W., Tsai, C.F. (2014). CANN: An intrusion detection system based on combining cluster center and nearest neighbors". Knowledge-based systems. Vol 78, pp. 13-21.

Liao, Y., Vemuri, V.R. (2002). Using k-nearest neighbor classifier for intrusion detection. Computers \& Security, vol 21, no. 5, pp. 439448.

Ma, Z., Kaban, A. (2013). K-Nearest-Neighbours with a Novel Similarity Measure for Intrusion Detection. UK Workshop for Computational Intelligence (UKCI), 2013, pp. 266-271.

Tavallae. M, Bagheri. E, Lu. W, Ghorbani A.A. (2009). A Detailed Analysis of the KDD CUP 99 Dataset.IEEE Symposium on Computational Intelligence for Security and Defense Applications. Pp. 1-6.

Tsai, C.F., Lin, C.Y. (2009). A triangle area based nearest neigbors approach to intrusion detection. Pattern recognition, vol 43, no 1. Pp. 222- 229. 
Tabel 1. Komposisi Dataset

\begin{tabular}{|c|c|c|c|c|}
\hline Nama Atribut & Rata-rata & Maksimum & Minimum & Varian \\
\hline Duration & $3.10 \times 10^{+2}$ & $40.29 \times 10^{+4}$ & "0.00 & $7.33 \times 10^{+6}$ \\
\hline src_bytes & $2.47 \times 10^{+4}$ & $3.82 \times 10^{+8}$ & 0.00 & $5.91 \times 10^{+12}$ \\
\hline dst_bytes & $3.55 \times 10^{+3}$ & $5.15 \times 10^{+6}$ & 0.00 & $8.02 \times 10^{+9}$ \\
\hline Land & $8.07 \times 10^{-5}$ & $1.00 \times 10^{+0}$ & 0.00 & $8.07 \times 10^{-5}$ \\
\hline wrong_fragment & $2.41 \times 10^{-2}$ & $3.00 \times 10^{+0}$ & 0.00 & $6.88 \times 10^{-2}$ \\
\hline urgent & $4.03 \times 10^{-5}$ & $1.00 \times 10^{+0}$ & 0.00 & $4.03 \times 10^{-5}$ \\
\hline hot & $2.01 \times 10^{-1}$ & $7.70 \times 10^{+1}$ & 0.00 & $4.72 \times 10^{+0}$ \\
\hline num_failed_logins & $1.21 \times 10^{-3}$ & $4.00 \times 10^{+0}$ & 0.00 & $2.10 \times 10^{-3}$ \\
\hline logged_in & $4.01 \times 10^{-1}$ & $1.00 \times 10^{+0}$ & 0.00 & $2.40 \times 10^{-1}$ \\
\hline num_compromised & $2.32 \times 10^{-1}$ & $8.84 \times 10^{+2}$ & 0.00 & $1.10 \times 10^{+2}$ \\
\hline root_shell & $1.57 \times 10^{-3}$ & $1.00 \times 10^{+0}$ & 0.00 & $1.57 \times 10^{-3}$ \\
\hline su_attempted & $1.37 \times 10^{-3}$ & $2.00 \times 10^{+0}$ & 0.00 & $2.42 \times 10^{-3}$ \\
\hline num_root & $2.54 \times 10^{-1}$ & $9.75 \times 10^{+2}$ & 0.00 & $1.34 \times 10^{+2}$ \\
\hline num_file_creations & $1.50 \times 10^{-2}$ & $4.00 \times 10^{+1}$ & 0.00 & $2.85 \times 10^{-1}$ \\
\hline num_shells & $3.63 \times 10^{-4}$ & $1.00 \times 10^{+0}$ & 0.00 & $3.63 \times 10^{-4}$ \\
\hline num_access_files & $4.40 \times 10^{-3}$ & $8.00 \times 10^{+0}$ & 0.00 & $9.86 \times 10^{-3}$ \\
\hline num_outbound_cmds & 0.00 & $0.00 \times 10^{+0}$ & 0.00 & 0.00 \\
\hline is_host_login & 0.00 & $0.00 \times 10^{+0}$ & 0.00 & 0.00 \\
\hline is_guest_login & $9.28 \times 10^{-3}$ & $1.00 \times 10^{+0}$ & 0.00 & $9.19 \times 10^{-3}$ \\
\hline count & $8.28 \times 10^{+1}$ & $5.11 \times 10^{+2}$ & $1.00 \times 10^{+0}$ & $1.30 \times 10^{+4}$ \\
\hline srv_count & $2.80 \times 10^{+1}$ & $5.11 \times 10^{+2}$ & $1.00 \times 10^{+0}$ & $5.33 \times 10^{+3}$ \\
\hline serror_rate & $2.80 \times 10^{-1}$ & $1.00 \times 10^{+0}$ & 0.00 & $1.97 \times 10^{-1}$ \\
\hline srv_serror_rate & $2.77 \times 10^{-1}$ & $1.00 \times 10^{+0}$ & 0.00 & $1.97 \times 10^{-1}$ \\
\hline rerror_rate & $1.16 \times 10^{-1}$ & $1.00 \times 10^{+0}$ & 0.00 & $9.95 \times 10^{-2}$ \\
\hline srv_rerror_rate & $1.18 \times 10^{-1}$ & $1.00 \times 10^{+0}$ & 0.00 & $1.02 \times 10^{-1}$ \\
\hline same_srv_rate & $6.69 \times 10^{-1}$ & $1.00 \times 10^{+0}$ & 0.00 & $1.91 \times 10^{-1}$ \\
\hline diff_srv_rate & $6.19 \times 10^{-2}$ & $1.00 \times 10^{+0}$ & 0.00 & $3.19 \times 10^{-2}$ \\
\hline srv_diff_host_rate & $9.75 \times 10^{-2}$ & $1.00 \times 10^{+0}$ & 0.00 & $6.67 \times 10^{-2}$ \\
\hline dst_host_count & $1.81 \times 10^{+2}$ & $2.55 \times 10^{+2}$ & 0.00 & $9.87 \times 10^{+3}$ \\
\hline dst_host_srv_count & $1.17 \times 10^{+2}$ & $2.55 \times 10^{+2}$ & 0.00 & $1.23 \times 10^{+4}$ \\
\hline dst_host_same_srv_rate & $5.20 \times 710^{-1}$ & $1.00 \times 10^{+0}$ & 0.00 & $2.01 \times 10^{-1}$ \\
\hline dst_host_diff_srv_rate & $8.16 \times 10^{-2}$ & $1.00 \times 10^{+0}$ & 0.00 & $3.46 \times 10^{-2}$ \\
\hline dst_host_same_src_port_rate & $1.48 \times 10^{-1}$ & $1.00 \times 10^{+0}$ & 0.00 & $9.53 \times 10^{-2}$ \\
\hline dst_host_srv_diff_host_rate & $3.24 \times 10^{-2}$ & $1.00 \times 10^{+0}$ & 0.00 & $1.24 \times 10^{-2}$ \\
\hline dst_host_serror_rate & $2.79 \times 10^{-1}$ & $1.00 \times 10^{+0}$ & 0.00 & $1.95 \times 10^{-1}$ \\
\hline dst_host_srv_serror_rate & $2.73 \times 10^{-1}$ & $1.00 \times 10^{+0}$ & 0.00 & $1.96 \times 10^{-1}$ \\
\hline dst_host_rerror_rate & $1.15 \times 10^{-1}$ & $1.00 \times 10^{+0}$ & 0.00 & $9.14 \times 10^{-2}$ \\
\hline dst_host_srv_rerror_rate & $1.16 \times 10^{-1}$ & $1.00 \times 10^{+0}$ & 0.00 & $9.86 \times 10^{-2}$ \\
\hline
\end{tabular}

Kharisma Muchammad, Thomas Brian 
Tabel 2. Komposisi Tiap Dataset

\begin{tabular}{|c|c|c|c|c|c|c|c|c|c|c|}
\hline Label & 1 & 2 & 3 & 4 & 5 & 6 & 7 & 8 & 9 & 10 \\
\hline "normal & 1345 & 1344 & 1345 & 1344 & 1345 & $\overline{1344}$ & 1345 & 1344 & 1345 & 1344 \\
\hline rootkit & 0 & 1 & 0 & 1 & 0 & 1 & 0 & 1 & 0 & 0 \\
\hline portsweep & 56 & 56 & 56 & 56 & 56 & 56 & 56 & 56 & 56 & 57 \\
\hline warezmaster & 0 & 0 & 0 & 1 & 1 & 1 & 1 & 1 & 1 & 1 \\
\hline satan & 69 & 69 & 69 & 69 & 69 & 69 & 69 & 69 & 68 & 68 \\
\hline multihop & 0 & 0 & 0 & 0 & 0 & 0 & 0 & 0 & 1 & 1 \\
\hline back & 20 & 20 & 20 & 20 & 19 & 19 & 19 & 19 & 20 & 20 \\
\hline ipsweep & 70 & 71 & 71 & 71 & 71 & 71 & 71 & 71 & 71 & 71 \\
\hline buffer_overflow & 0 & 1 & 1 & 1 & 1 & 0 & 1 & 1 & 0 & 0 \\
\hline warezclient & 19 & 18 & 18 & 18 & 18 & 18 & 18 & 18 & 18 & 18 \\
\hline imap & 1 & 0 & 0 & 0 & 1 & 0 & 0 & 1 & 1 & 1 \\
\hline ftp_write & 1 & 0 & 0 & 0 & 0 & 0 & 0 & 0 & 0 & 0 \\
\hline spy & 0 & 0 & 0 & 0 & 0 & 1 & 0 & 0 & 0 & 0 \\
\hline phf & 0 & 0 & 0 & 0 & 0 & 0 & 1 & 1 & 0 & 0 \\
\hline nmap & 30 & 30 & 30 & 30 & 30 & 30 & 29 & 29 & 29 & 29 \\
\hline pod & 4 & 4 & 4 & 3 & 3 & 4 & 4 & 4 & 4 & 4 \\
\hline smurf & 52 & 53 & 53 & 53 & 53 & 53 & 53 & 53 & 53 & 53 \\
\hline teardrop & 19 & 19 & 19 & 19 & 19 & 19 & 18 & 18 & 19 & 19 \\
\hline guess_passwd & 1 & 1 & 1 & 1 & 1 & 1 & 1 & 1 & 1 & 1 \\
\hline loadmodule & 1 & 0 & 0 & 0 & 0 & 0 & 0 & 0 & 0 & 0 \\
\hline land & 0 & 0 & 0 & 0 & 0 & 0 & 1 & 0 & 0 & 0 \\
\hline neptune & 791 & 792 & 792 & 792 & 792 & 792 & 792 & 792 & 792 & 792 \\
\hline
\end{tabular}

Tabel 3. Hasil Eksperimen

\begin{tabular}{cccccc}
\hline \hline Kawal $_{\text {akhir }}$ & K $_{\text {akurasi }}$ & Sensitivity & Specificity & Reduction \\
\hline \hline 60 & 60 & 0.775 & 0.712 & 0.828 & $\mathbf{0 . 3 8 6}$ \\
60 & 40 & $\mathbf{0 . 8 3 8}$ & 0.785 & $\mathbf{0 . 8 8 3}$ & 0.126 \\
40 & 40 & 0.738 & 0.671 & 0.795 & 0.271 \\
60 & 30 & 0.834 & $\mathbf{0 . 8 0 2}$ & 0.862 & 0.113 \\
\hline \hline
\end{tabular}

Tabel 4. Confusion Matrix pada 6060

\begin{tabular}{|c|c|c|c|c|c|}
\hline \multirow[t]{2}{*}{ Aktual } & \multicolumn{5}{|c|}{ Prediksi } \\
\hline & Dos & probe & $\mathrm{u} 2 \mathrm{r}$ & r2l & normal \\
\hline dos & 5580 & 973 & 0 & 3 & 2315 \\
\hline probe & 473 & 939 & 0 & 10 & 832 \\
\hline $\mathrm{u} 2 \mathrm{r}$ & 0 & 0 & 1 & 0 & 10 \\
\hline $\mathrm{r} 21$ & 1 & 16 & 0 & 90 & 102 \\
\hline normal & 1205 & 1111 & 24 & 144 & 10961 \\
\hline
\end{tabular}

Kharisma Muchammad, Thomas Brian 
Tabel 5. Confusion Matrix pada 6040

\begin{tabular}{|c|c|c|c|c|c|}
\hline \multirow[t]{2}{*}{ Aktual } & \multicolumn{5}{|c|}{ Prediksi } \\
\hline & Dos & probe & $\mathbf{u} 2 r$ & r2l & normal \\
\hline dos & 5259 & 1801 & 0 & 31 & 1780 \\
\hline probe & 1029 & 725 & 0 & 14 & 486 \\
\hline $\mathrm{u} 2 \mathrm{r}$ & 1 & 0 & 0 & 0 & 10 \\
\hline $\mathrm{r} 21$ & 6 & 12 & 0 & 39 & 152 \\
\hline normal & 1011 & 410 & 9 & 143 & 11872 \\
\hline
\end{tabular}

Tabel 6. Confusion Matrix pada 4040

\begin{tabular}{|c|c|c|c|c|c|}
\hline \multirow[t]{2}{*}{ Aktual } & \multicolumn{5}{|c|}{ Prediksi } \\
\hline & Dos & probe & $\mathbf{u} 2 \mathbf{r}$ & r2l & normal \\
\hline dos & 5074 & 937 & 0 & 48 & 2812 \\
\hline probe & 586 & 870 & 0 & 22 & 776 \\
\hline $\mathrm{u} 2 \mathrm{r}$ & 0 & 1 & 0 & 0 & 10 \\
\hline $\mathrm{r} 21$ & 26 & 11 & 2 & 41 & 129 \\
\hline normal & 1447 & 1081 & 22 & 199 & 10696 \\
\hline
\end{tabular}

Tabel 7. Confusion Matrix pada 6030

\begin{tabular}{|c|c|c|c|c|c|}
\hline \multirow[t]{2}{*}{ Aktual } & \multicolumn{5}{|c|}{ Prediksi } \\
\hline & Dos & probe & $\mathrm{u} 2 \mathrm{r}$ & r2l & normal \\
\hline dos & 5412 & 1860 & 2 & 38 & 1559 \\
\hline probe & 996 & 721 & 0 & 6 & 531 \\
\hline $\mathrm{u} 2 \mathrm{r}$ & 2 & 1 & 0 & 0 & 8 \\
\hline $\mathrm{r} 21$ & 11 & 5 & 0 & 46 & 147 \\
\hline normal & 1072 & 555 & 11 & 211 & 11596 \\
\hline
\end{tabular}

Kharisma Muchammad, Thomas Brian 